\begin{tabular}{llrr}
\hline \hline Volume: & 3 & E-ISSN: & $2655-1942$ \\
Number: & 1 & Terbitan: & April 2020 \\
Page : & $29-41$ & & \\
\hline
\end{tabular}

\title{
Hambatan Implementasi Pencegahan Tindak Pidana Korupsi pada Pelaksanaan Program Dana Desa di Kabupaten Gresik
}

\author{
Emmilia Rusdiana, Pudji Astuti, Nurul Hikmah, Gelar Ali Ahmad \\ Fakutas Ilmu Sosial dan Hukum, Universitas Negeri Surabaya, Kampus UNESA Ketintang \\ Surabaya. \\ Email: emmiliarusdiana@unesa.ac.id
}

\begin{abstract}
Abstrak
Tindak pidana korupsi adalah extra ordinary crime, yakni tindak pidana yang memerlukan keterlibatan banyak pihak, cara yang tidak biasa dan melibatkan komitmen dari masyarakat. Salah satu upaya pencegahan tindak pidana korupsi adalah melalui pemberian contoh-contoh berbagai usaha mencegah dan menentang korupsi serta strategi dan rencana aksi pemberantasan korupsi dan integritas dan nilai-nilai antikorupsi. Sehubungan dengan pengawasan pada penggunaan anggaran negara melalui dana desa, maka tujuan penelitian ini adalah menganalisis hambatan dalam penerapan pencegahan korupsi pada penggunaan dana desa. Metode penelitian yang digunakan adalah penelitian eksploratif dengan analisis data secara deskriptif kualitatif. Hasil penelitian menunjukkan bahwa perwujudan pencegahan korupsi pada penggunaan dana desa pada Dinas Pemerintahan Masyarakat dan Desa (PMD)dan Pemerintah Desa Suci, Desa Yosowilangun dan Desa Giri pada Pencegahan korupsi adalah pertama, pemahaman yang rendah mengenai gerakan anti korupsi berupa pemenuhan unsur monitoring dan evaluasi, pemenuhan dokumen saat perencanaan dan pelaksanaan dan administrasi kegiatan. Kedua, bentuk pencegahan korupsi adalah dengan munculnya rasa ketakutan untuk melakukan pelanggaran pada peraturan pelaksanaan penggunaan dana desa tersebut. Ketiga, pembahasan mengenai Pencegahan korupsi seakan-akan merupakan kajian yang baru dan tabu untuk diadakan pembahasan lebih lanjut.
\end{abstract}

Kata Kunci: pencegahan korupsi, dana desa, Kabupaten Gresik

\begin{abstract}
Corruption is an extraordinary crime, namely a crime that requires the involvement of many parties, an unusual way and involves the commitment of the community. One of the efforts to prevent corruption is through providing examples of various efforts to prevent and oppose corruption as well as strategies and action plans to eradicate corruption and anti-corruption integrity and values. In connection with the supervision of the use of the state budget through village funds, the purpose of this study is to analyze obstacles in the application of corruption prevention to the use of village funds. The research method used was exploratory research with descriptive qualitative data analysis. The results showed that the manifestation of the prevention of corruption in the use of village funds in the Community and Village Administration Office (PMD) and the Village Government of the Holy, Yosowilangun and Giri Villages in Corruption Prevention was first, a low understanding of the anticorruption movement in the form of monitoring and evaluation elements, fulfillment of documents when planning and implementing and administering activities. Second, a form of corruption prevention is the emergence of a fear of violating regulations governing the use of village funds.
\end{abstract}




$\begin{array}{llrr}\text { Volume: } & 3 & \text { E-ISSN: } & 2655-1942 \\ \text { Number: } & 1 & \text { Terbitan: } & \text { April 2020 } \\ \text { Page : } & 29-41 & & \end{array}$

Third, the discussion on corruption prevention seems to be a new and taboo study for further discussion.

Keywords: corruption prevention, village funds, Gresik Regency

\section{A. Latar Belakang Masalah}

Korupsi sebagai tindak pidana yang melawan hukum, memperkaya diri sendiri dan merugikan keuangan negara. Tindak pidana ini tergolong dalam kejahatan dengan motif ekonomi, dilakukan oleh orang-orang yang memiliki jabatan tertentu dan dilakukan secara sistematis (white collar crime), kejahatan ini merupakan musuh utama Bangsa Indonesia selain tindak pidana narkotika, dan terorisme. Pemberantasan korupsi memerlukan penegakan hukum berupa penanggulangan (represif) namun langkah pencegahan (preventif) harus lebih diutamakan.

Tindak pidana korupsi juga dapat terjadi penggunaan Dana Desa. Dana desa ini diprioritaskan untuk membiayai pembangunan dan pemberdayaan masyarakat yang ditujukan untuk meningkatkan kesejahteraan masyarakat desa, peningkatan kualitas hidup manusia serta penanggulangan kemiskinan dan dituangkan dalam Rencana Kerja Pemerintah Desa. Dana Desa dapat digunakan untuk membiayai kegiatan yang tidak termasuk dalam prioritas penggunaan Dana Desa setelah mendapat persetujuan bupati/walikota dengan memastikan pengalokasian Dana Desa untuk kegiatan yang menjadi prioritas telah terpenuhi dan/atau kegiatan pembangunan dan pemberdayaan masyarakat telah terpenuhi ${ }^{1}$.

Penggunaan dana desa ternyata juga diiringi dengan adanya penyimpangan penggunaan dana tersebut. Salah satunya dari pihak Kepolisian Resor Gowa ${ }^{2}$ kini tengah menyelidiki dugaan penyimpangan yang dilakukan oleh sekitar 32 kepala desa atas dana desa yang diterima masing-masing kepala desa. Temuan ini berdasarkan hasil pendalaman tim intelijen yang disebar di ke 32 desa di Kabupaten Gowa, tim intelijen melakukan penyelidikan dengan berfokus kepada pengecekan dokumen yang berisi penyerapan anggaran dibandingkan

\footnotetext{
${ }^{1}$ Direktorat jenderal Perimbangan Keuangan Kemenmterian Keuangan. Diakses 17 April 2019. Http://www.djpk.kemenkeu.go.id/?ufaq=bagaimana-penggunaan-dana-desa

${ }^{2}$ risman. Polres gowa usut penyalahgunaan 32 kasus dana desa. Ditulis pada 6 maret 2019. Https://suarapalu.com/polres-gowa-usut-penyalahgunaan-32-kasus-dana-desa/.
} 


\begin{tabular}{llrr}
\hline \hline Volume: & 3 & E-ISSN: & $2655-1942$ \\
Number: & 1 & Terbitan: & April 2020 \\
Page : & $29-41$ & & \\
\hline
\end{tabular}

dengan realitas di lapangan atau kondisi fisiknya. Ternyata faktanya ada beberapa kejanggalan karena dari laporan penyerapan dana desa tidak sesuai dengan kondisi fisik pembangunan, bahkan ada yang tidak dikerjakan sama sekali sedangkan dalam laporan penyerapan dicantumkan. Pengawasan terhadap dana desa semakin kuat. Pada 20 Oktober $2017^{3}$ tiga institusi negara yakni Kementerian Desa PDTT, Kementerian Dalam negeri dan Kepolisian Rebuplik Indonesia sepakat mengawasi jalannya penggunaan dana desa di seluruh desa se-Indonesia. Kesepakatan itu ditandatangani oleh Eko Putro Sandjojo selaku Menteri Desa, Pembangunan, Daerah Tertinggal dan Transmigrasi, Tjahjo Kumolo selaku Menteri Dalam Negeri dan Muhammad Tito Karnavian, ketiganya siap menggerakkan seluruh jajarannya mengawasi penggunaan dana desa. Ketiga institusi ini sepakat untuk bekerja keras mengawasi seluruh desa mengenai upaya mengelola dana desa, artinya sejak kesepakatan ditandatangani berarti persoalan dana desa sudah tidak dapat main-main lagi. Kepolisian sekarang mengalami wewenang melakukan pengawasan dan dapat melakukan penanganan jika terjadi permasalahan pada penggunaan dana desa.

Penanganan berupa penanggulangan tindak pidana korupsi tidak akan terjadi kalau pencegahan atas tindak pidana korupsi telah diupayakan. Salah satu wujud pencegahan tindak pidana ini adalah dengan mewujudkan gerakan anti korupsi. Peran lembaga pendidikan atau dunia universitas sangat strategis dalam upaya percepatan pemberantasan tindak pidana korupsi. kerjasama KPK-Perguruan Tinggi dalam bidang pencegahan korupsi antara lain melalui Pendidikan Anti-korupsi/kurikulum anti-korupsi, penelitian, sosialisasi dan partner kampanye antikorupsi. Berbagai kegiatan pencegahan korupsi juga secara aktif dilakukan oleh Perguruan Tinggi, misalnya kampanye, sosialisasi, pendidikan anti korupsi dan kegiatan lainnnya yang terus menerus menginisiasi, mendorong, meningkatkan gerakan anti Korupsi yang lebih masif.

Wujud gerakan anti korupsi adalah dengan memberikan contoh-contoh berbagai usaha mencegah dan menentang korupsi serta strategi dan rencana aksi pemberantasan korupsi dan

${ }^{3}$ Aryadji. Awas, Sekarang Polisi Ikut Awasi Dana Desa. Diakses tanggal 23 Oktober 2017. http://www.berdesa.com/awas-sekarang-polisi-ikut-awasi-dana-desa/ 


\begin{tabular}{llrr} 
Volume: & 3 & E-ISSN: & $2655-1942$ \\
Number: & 1 & Terbitan: & April 2020 \\
Page : & $29-41$ & & \\
\hline
\end{tabular}

integritas dan nilai-nilai antikorupsi, jadi permasalahan yang dapat diajukan adalah mengenai hambatan dalam penerapan pencegahan korupsi pada penggunaan dana desa sebagai upaya pencegahan tindak pidana korupsi.

Tujuan penelitian ini adalah untuk memaparkan hambatan atas perwujudan pencegahan korupsi pada penggunaan dana desa. Hasil penelitian ini dapat digunakan oleh pemerintah daerah atau pemerintah kota juga desa-desa berupa materi penyuluhan yang sesuai dengan kebutuhan masyarakat desa berdasarkan penggunaan dana desa.

\section{B. Metode Penelitian}

Jenis penelitian menggunakan penelitian eksploratif dengan pendekatan induktif, studi eksploratif $^{4}$ adalah penelitian yang bertujuan untuk menggali secara luas tentang sebab-sebab atau hal-hal yang mempengaruhi terjadinya sesuatu. Penelitian eksploratif adalah penelitian yang bertujuan untuk memetakan suatu objek secara relatif mendalam atau dengan kata lain penelitian eksploratif adalah penelitian yang dilakukan untuk mencari sebab atau hal-hal yang mempengaruhi terjadinya sesuatu dan dipakai manakala kita belum mengetahui secara persis dan spesifik mengenai objek penelitian. Peneliti mengungkapkan penelitian eksploratif ini secara kualitatif. Adapun pendekatan penelitian adalah dengan pendekatan induktif, yaitu suatu pendekatan dengan mengambil suatu kesimpulan secara umum dari fakta-fakta nyata yang ada di lapangan. Sumber data yang digunakan adalah data primer dan sekunder. Data primer yakni peneliti menggunakan data yang diperoleh dari informan. Informan terdiri dari kepala dinas PMD kabupaten Gresik, Kepala Bidang Pemberdayaan Masyarakat, Kepala Desa Suci, Kepala Desa Yosowilangun, Kepala Desa Giri dan Kepala Desa Roomo. Kedua yaitu data sekunder. Data ini diperoleh dari buku-buku, jurnal dan referensi lain yang mendukung. Teknik pengumpulan data menggunakan metode Interview (wawancara) atau

\footnotetext{
${ }^{4}$ Suharsimi Arikunto, 2013. Prosedur Penelitian Suatu Pendekatan Praktik. Jakarta. Rineka Cipta.
} 


\begin{tabular}{llrr} 
Volume: & 3 & E-ISSN: & $2655-1942$ \\
Number: & 1 & Terbitan: & April 2020 \\
Page : & $29-41$ & & \\
\hline
\end{tabular}

kuesionar lisan ${ }^{5}$. penelitian ini menggunakan teknik wawancara tidak terstruktur adalah wawancara bebas. Analisis data menggunakan deskriptif kualitatif.

\section{Hasil dan Pembahasan}

Gerakan anti korupsi berupa contoh-contoh berbagai usaha mencegah dan menentang korupsi dapat digunakan sebagai strategi dan rencana aksi pemberantasan korupsi dan integritas dan nilai-nilai antikorupsi. Gerakan anti korupsi, gerakan ini merupakan upaya dalam pencegahan tanpa hukum pidana (prevention without punishment). Upaya pencegahan dan penanggulangan kejahatan perlu ditempuh dengan pendekatan kebijakan, dalam arti ada keterpaduan antara kebijakan/politik kriminal dengan kebijakan/politik sosial, serta ada keterpaduan antara upaya penanggulangan kejahatan melalui sarana penal dengan sarana non penal. Pada dasarnya korupsi terjadi karena adanya faktor internal (niat) dan faktor eksternal (kesempatan). Niat lebih terkait dengan faktor individu yang meliputi perilaku dan nilai-nilai yang dianut, sedangkan kesempatan terkait dengan sistem yang berlaku. Upaya pencegahan korupsi dapat dimulai dengan menanamkan nilai-nilai anti korupsi pada semua individu. Nilai-nilai anti korupsi yang akan dibahas meliputi kejujuran, kepedulian, kemandirian, kedisiplinan, pertanggungjawaban, kerja keras, kesederhanaan, keberanian, dan keadilan. Nilai-nilai inilah yang akan mendukung prinsip-prinsip anti korupsi untuk dapat dijalankan dengan baik.

Nilai-nilai anti korupsi itu perlu diterapkan oleh setiap individu untuk dapat mengatasi faktor eksternal agar korupsi tidak terjadi. Untuk mencegah terjadinya faktor eksternal, Selain memiliki nilai-nilai anti korupsi, setiap individu perlu memahami dengan mendalam prinsipprinsip anti korupsi yaitu akuntabilitas, transparansi, kewajaran, kebijakan, dan kontrol kebijakan dalam suatu organisasi/institusi/masyarakat. Oleh karena itu hubungan antara prinsip-prinsip dan nilai-nilai anti korupsi merupakan satu kesatuan yang tidak dapat dipisahkan.

\footnotetext{
${ }^{5}$ Sugiyono. 2010. Metode Penelitian Pendidikan Pendekatan Kuantitatif, kualitatif, dan R\&D. Bandung: Alfabeta.)
} 


$\begin{array}{llrr}\text { Volume: } & 3 & \text { E-ISSN: } & 2655-1942 \\ \text { Number: } & 1 & \text { Terbitan: } & \text { April 2020 } \\ \text { Page : } & 29-41 & & \end{array}$

Nilai-nilai anti korupsi yang penting untuk mencegah faktor internal terjadinya korupsi, pembahasan prinsip-prinsip anti-korupsi meliputi akuntabilitas, transparansi, kewajaran, kebijakan, dan kontrol kebijakan, untuk mencegah faktor eksternal penyebab korupsi. Akuntabilitas adalah kesesuaian antara aturan dan pelaksanaan kerja. Semua lembaga mempertanggungjawabkan kinerjanya sesuai aturan main baik dalam bentuk konvensi (de facto) maupun konstitusi (de jure), baik pada level budaya (individu dengan individu) maupun pada level Lembaga, ada dalam Public Good Governance: Sebuah Paparan Singkat, Jakarta: Bappenas RI ${ }^{6}$. Prinsip adalah transparansi. Prinsip transparansi ini penting karena pemberantasan korupsi dimulai dari transparansi dan mengharuskan semua proses kebijakan dilakukan secara terbuka, sehingga segala bentuk penyimpangan dapat diketahui oleh publik ${ }^{7}$. Prinsip lainnya adalah prinsip kewajaran (fairness). Prinsip ini ditujukan untuk mencegah terjadinya manipulasi (ketidakwajaran) dalam penganggaran, baik dalam bentuk mark up maupun ketidakwajaran lainnya. Sifat-sifat prinsip kewajaran ini terdiri dari lima hal penting yaitu komprehensif dan disiplin, fleksibilitas, terprediksi, kejujuran, dan informatif. Prinsip selanjutnya adalah prinsip kebijakan. Pembahasan mengenai prinsip ini ditujukan agar mahasiswa dapat mengetahui dan memahami kebijakan anti korupsi. Kebijakan ini berperan untuk mengatur tata interaksi agar tidak terjadi penyimpangan yang dapat merugikan negara dan masyarakat. Prinsip terakhir adalah kontrol kebijakan, ini sebagai upaya agar kebijakan yang dibuat betul-betul efektif dan mengeliminasi semua bentuk korupsi. Pada prinsip ini, akan dibahas mengenai lembaga-lembaga pengawasan di Indonesia, self-evaluating organization, reformasi sistem pengawasan di Indonesia, problematika pengawasan di Indonesia. Bentuk kontrol kebijakan berupa partisipasi, evolusi dan reformasi.

Dana Desa adalah dana yang bersumber dari Anggaran Pendapatan dan Belanja Negara yang diperuntukkan bagi Desa dan Desa Adat yang ditransfer melalui Anggaran Pendapatan dan Belanja Daerah kabupaten/kota dan digunakan untuk membiayai penyelenggaran

\footnotetext{
${ }^{6}$ Kementerian PPN/Bappenas Ri, 2014. Hasil Kajian Background Study Rpjmn 2015-2019 Pembangunan Bidang Aparatur Negara.. Direktorat Aparatur Negara Kementerian Perencanaan Pembangunan Nasional/ Badan Perencanaan Pembangunan Nasional Tahun 2014.

${ }^{7}$ Prasojo, E. (2005). Demokrasi di Negeri Mimpi: Catatan Kritis Pemilu 2004 dan Good Governance. Depok.
} 


$\begin{array}{llrr}\text { Volume: } & 3 & \text { E-ISSN: } & 2655-1942 \\ \text { Number: } & 1 & \text { Terbitan: } & \text { April 2020 } \\ \text { Page : } & 29-41 & & \end{array}$

pemerintahan, pembangunan, serta pemberdayaan masyarakat, dan kemasyarakatan. Fokus penting dari penyaluran dana ini lebih terkait pada implementasi pengalokasian Dana Desa agar dapat sesempurna gagasan para inisiatornya. Skenario awal Dana Desa ini diberikan dengan mengganti program pemerintah yang dulunya disebut PNPM, namun dengan berlakunya Dana Desa ini, dapat menutup kesempatan beberapa pihak asing untuk menyalurkan dana ke daerah di Indonesia dengan program-program yang sebenarnya juga dapat menjadi pemicu pembangunan daerah.

Pelaksanaan kegiatan yang dibiayai dari Dana Desa berpedoman pada pedoman teknis yang ditetapkan oleh bupati/walikota mengenai kegiatan yang dibiayai dari Dana Desa. Pelaksanaan kegiatan yang dibiayai dari Dana Desa diutamakan dilakukan secara swakelola dengan menggunakan sumber daya/bahan baku lokal, dan diupayakan dengan lebih banyak menyerap tenaga kerja dari masyarakat Desa setempat. Undang-Undang Nomor 6 Tahun 2014 tentang Desa menjadi tonggak perubahan paradigma pengaturan desa. Desa tidak lagi dianggap sebagai objek pembangunan, melainkan ditempatkan menjadi subjek dan ujung tombak pembangunan dan peningkatan kesejahteraan masyarakat. Desa diberikan kewenangan untuk mengatur dan mengurus urusan pemerintahan, kepentingan masyarakat setempat berdasarkan prakarsa masyarakat, hak asal usul, adat istiadat, dan nilai sosial budaya masyarakat desa yang pengaturannya berpedoman pada 13 azas.

Peraturan tentang alokasi prioritas penggunaan dana desa untuk tahun 2018 telah diterbitkan oleh Menteri Desa, Pembangunan Daerah Tertinggal dan Transmigrasi Republik Indonesia (Kemendesa). Peraturan Menteri Kemendesa Nomor 19 Tahun 2017 (Permendes 19 Tahun 2017) ini mengatur secara detail tentang prioritas dana desa tahun 2018. Penetapan prioritas penggunaan dana Desa ini bertujuan sebagai pedoman dan acuan bagi penyelenggaraan kewenangan, acuan untuk Pemerintah Daerah Kabupaten/Kota dalam menyusun pedoman teknis penggunaan Dana Desa dan acuan bagi Pemerintah Daerah Pusat dalam pemantauan dan evaluasi pelaksanaan penggunaan Dana Desa. lima point prioritas dalam penggunaan dana desa antara lain: 


\begin{tabular}{llrr}
\hline \hline Volume: & 3 & E-ISSN: & $2655-1942$ \\
Number: & 1 & Terbitan: & April 2020 \\
Page : & $29-41$ & & \\
\hline
\end{tabular}

1. Prioritas Penggunaan Dana Desa untuk membiayai pelaksanaan program dan kegiatan di bidang pembangunan Desa dan pemberdayaan masyarakat Desa.

2. Prioritas penggunaan Dana Desa diutamakan untuk membiayai pelaksanaan program dan kegiatan yang bersifat lintas bidang.

3. Program dan kegiatan sebagaimana dimaksud pada ayat (2) antara lain bidang kegiatan produk unggulan desa atau kawasan perdesaan, BUM Desa atau BUM Desa Bersama, embung, dan sarana olahraga desa sesuai dengan kewenangan Desa.

4. Pembangunan sarana olahraga desa sebagaimana dimaksud pada ayat (3) merupakan unit usaha yang dikelola oleh BUM Desa atau BUM Desa Bersama.

5. Prioritas penggunaaan Dana Desa sebagaimana dimaksud pada ayat (1) wajib dipublikasikan oleh Pemerintah Desa kepada masyarakat Desa di ruang publik yang dapat diakses masyarakat Desa.

Hal yang penting yang dapat diterapkan dalam pengelolaan Dana Desa dengan melibatkan masyarakat adalah perlunya melakukan kegiatan dengan pola swakelola, menggunakan tenaga kerja setempat, dan memanfaatkan bahan baku lokal yang ada di desa. Dengan pola swakelola, berarti diupayakan perencanaan dan pelaksanaan kegiatan tersebut dilakukan secara mandiri oleh Desa, sehingga uang yang digunakan untuk pembangunan tersebut tidak akan mengalir keluar desa. Dengan menggunakan tenaga kerja setempat, diharapkan pelaksanaan kegiatan tersebut dapat menyerap tenaga kerja dan memberikan pendapatan bagi mereka yang bekerja. Sementara penggunaan bahan baku lokal diharapkan akan memberikan penghasilan kepada masyarakat yang memiliki bahan baku tersebut. Penggunaan Dana Desa untuk Bidang Pembangunan Desa diarahkan untuk Pengadaan, Pembangunan, Pengembangan, dan Pemeliharaan.

Hasil penelitian pada Dinas Pemberdayaan Masyarakat Desa (Dinas PMD) Kabupaten Gresik menunjukkan bahwa program penggunaan dana desa oleh para pelaksana program disesuaikan dengan Peraturan Bupati Gresik Nomor 55 Tahun 2016 Tentang Kedudukan, Susunan Organisasi, Tugas, Fungsi dan Tata Kerja Dinas Pemberdayaan Masyarakat Dan Desa Kabupaten Gresik. Hal ini sesuai dengan peraturan bahwa pelaksanaan kegiatan yang 


$\begin{array}{llrr}\text { Volume: } & 3 & \text { E-ISSN: } & 2655-1942 \\ \text { Number: } & 1 & \text { Terbitan: } & \text { April 2020 } \\ \text { Page : } & 29-41 & & \end{array}$

dibiayai dari Dana Desa berpedoman pada pedoman teknis yang ditetapkan oleh bupati/walikota mengenai kegiatan yang dibiayai dari Dana Desa.

Pelaksanaan monitoring dan evaluasi kegiatan dana desa Tahun Anggaran 2019 Kabupaten Gresik dengan mengadakan pengecekan pada standar berikut ini :

- kesesuaian dan kepatuhan pada peraturan pelaksanaan

- dokumen perencanaan berupa Rencana Pembangunan Jangka Menengah Desa (RPJMDesa), Rencana Kerja Pemerintah Desa (RKPDesa), Anggaran Pendapatan dan Belanja Desa (APBDesa), Berita Acara Musyawarah Desa (Berita Acara Musdes).

- dokumen pelaksanaan berupa Surat Keputusan (SK), Rencana Anggaran dan Biaya (R\&B) dan gambar, jadwal kegiatan, pengadaan barang dan jasa, Surat Permintaan Pembayaran (SPP), Surat Pernyataan Tanggung Jawab Belanja (SPTB).

- pelaporan/pertanggungjawaban berupa SK, R\&B dan gambar, jadwal kegiatan, pengadaan barang dan jasa, SPP dan SPTB.

- dokumen penatausahaan keuangan berupa Buku kas, buku kas pembantu, buku bank, buku bantu pajak, bukti transaksi keuangan.

Tabel berikut berisikan data evaluasi dan monitoring pada pelaksanaan kegiatan dana desa pada Desa Suci, Yosowilangun dan Giri Tahun Anggaran 2019 Kabupaten Gresik :

\begin{tabular}{|c|c|c|c|c|}
\hline Unsur evaluasi & Dokumen evaluasi & Desa Suci & $\begin{array}{c}\text { Desa } \\
\text { Yosowilangun }\end{array}$ & Desa Giri \\
\hline $\begin{array}{l}\text { Kesesuaian dan } \\
\text { kepatuhan pada } \\
\text { peraturan } \\
\text { pelaksanaan }\end{array}$ & $\begin{array}{l}\text { RPJMDesa, } \\
\text { RKPDesa, } \\
\text { APBDesa, Berita } \\
\text { Acara Musdes }\end{array}$ & $\begin{array}{l}\text { RKPDesa } \\
\text { tidak ada }\end{array}$ & Ada & Ada \\
\hline $\begin{array}{l}\text { Dokumen } \\
\text { administrasi } \\
\text { perencanaan } \\
\text { kegiatan }\end{array}$ & $\begin{array}{l}\text { RPJMDesa, } \\
\text { RKPDesa, } \\
\text { APBDesa, Berita } \\
\text { Acara Musdes }\end{array}$ & $\begin{array}{l}\text { RKPDesa } \\
\text { tidak ada }\end{array}$ & Ada & Ada \\
\hline $\begin{array}{l}\text { Dokumen } \\
\text { administrasi } \\
\text { pelaksanaan } \\
\text { kegiatan }\end{array}$ & $\begin{array}{l}\text { SK, R\&B dan } \\
\text { gambar, jadwal } \\
\text { kegiatan, pengadaan } \\
\text { barang dan jasa, }\end{array}$ & $\begin{array}{l}\text { Pengadaan } \\
\text { barang dan } \\
\text { jasa tidak ada }\end{array}$ & Ada & $\begin{array}{l}\text { pengadaan } \\
\text { barang dan } \\
\text { jasa, SPP dan } \\
\text { SPTB tidak }\end{array}$ \\
\hline
\end{tabular}


Law, Development \& Justice Review

\begin{tabular}{llrr} 
Volume: & 3 & E-ISSN: & $2655-1942$ \\
Number: & 1 & Terbitan: & April 2020 \\
Page : & $29-41$ & & \\
\hline
\end{tabular}

\begin{tabular}{|l|l|l|l|l|}
\hline & SPP, SPTB & & ada \\
\hline $\begin{array}{l}\text { Pelaporan/ } \\
\text { pertanggungjawaban }\end{array}$ & $\begin{array}{l}\text { Banner informasi } \\
\text { APBDes 2019, } \\
\text { laporan APBDes } \\
2018, \text { proyek } \\
\text { kegiatan dan foto } \\
\text { kegiatan }\end{array}$ & $\begin{array}{l}\text { Informasi } \\
\text { proyek } \\
\text { kegiatan tidak } \\
\text { ada }\end{array}$ & $\begin{array}{l}\text { Informasi } \\
\text { laporan } \\
\text { APBDes tidak } \\
\text { ada }\end{array}$ & \\
\hline $\begin{array}{l}\text { Dokumen } \\
\text { penatausahaan } \\
\text { keuangan }\end{array}$ & $\begin{array}{l}\text { Buku kas, buku kas } \\
\text { pembantu, buku } \\
\text { bank, buku bantu } \\
\text { pajak, bukti } \\
\text { transaksi keuangan. }\end{array}$ & Ada & Ada & ada \\
\hline
\end{tabular}

Pada berita acara hasil monitoring dan evaluasi pada pelaksanaan kegiatan dana desa Tahun Anggaran 2019 Kabupaten Gresik mencantumkan adanya prioritas penggunaan dengan berdasarkan pada kesesuaian dan kepatuhan terhadap peraturan pelaksanaan, bahwa harus ada kesesuaian dengan RPJM Desa, RKPdesa dan APBDesa.

Pada penggunaan dana desa periode I pada Desa Suci Kecamatan Manyar Kabupaten Gresik adalah ddengan dana sebesar Rp. 819.630.000,- (delapan ratus Sembilan belas ribu enam ratus tiga puluh ribu rupiah). Salah satu contoh kegiatan adalah dengan adanya Surat Keputusan Kepala Desa Suci Kecamatan Manyar Kabupaten Gresik mengenai tim pelaksana teknis kegiatan bidang pembangunan (pembangunan drainase RT 03 dan RT 04) Dana Desa Tahun Anggaran 2019).

Hasil pada berita acara hasil monitoring dan evaluasi pada pelaksanaan kegiatan dana desa Tahun Anggaran 2019 Kabupaten Gresik mencantumkan adanya prioritas penggunaan dengan berdasarkan pada kesesuaian dan kepatuhan terhadap peraturan pelaksanaan, dan hasilnya adalah bahwa Desa Suci tidak memiliki dokumen perencanaan berupa RKP Desa, dokumen pengadaan barang dan jasa juga tidak, serta ketiadaan papan informasi proyek kegiatan.

Informasi dari ketua tim pelaksana teknis kegiatan bidang pembangunan (pembangunan drainase RT.03 RW. 04) dana desa tahun anggaran 2019 Desa Suci Kecamatan Manyar Kabupaten Gresik, yang sekaligus sekretaris desa menyatakan bahwa frase pencegahan 


\begin{tabular}{llrr} 
Volume: & 3 & E-ISSN: & $2655-1942$ \\
Number: & 1 & Terbitan: & April 2020 \\
Page : & $29-41$ & & \\
\hline
\end{tabular}

korupsi belum diketahui mengenai definisinya, maknanya dan wujud konkritnya apalagi dalam pelaksanan kegiatan pada penggunaan dana desa. Dari hasil penelitian berupa hasil observasi yang dilakukan peneliti di atas menunjukkan bahwa ada pengetahuan serta pemahaman bahwa pemerintah desa dan tim pelaksana kegiatan desa sebatas pada penyesuaian pada peraturan pelaksanaan yang melandasi penggunaan dana desa, jadi dapat ditarik kesimpulan bahwa:

Pertama, pemahaman yang rendah mengenai upaya untuk mengadakan pencegahan antikorupsi berupa pemenuhan unsur monitoring dan evaluasi, yakni pemenuhan dokumen sebelum pelaksanaan kegiatan. Wujud nyata Pencegahan korupsi itu, salah satunya adalah diwujudkan dalam bentuk kesesuaian atas kelengkapan dokumen (prioritas penggunaaan berkaitan dengan kesesuaian dan kepatuhan terhadap peraturan pelaksanaan, dokumen administrasi pelaksanaan kegiatan, dan dokumen penatausahaan keuangan), tetapi juga kesesuaian antara fakta dengan dokumen, maksudnya adalah dokumen adalah bukti tertulis atas pelaksanaan suatu kegiatan. Padahal setiap unsur dan dokumen evaluasi dapat menunjukkan bahwa ada nilai-nilai anti korupsi meliputi kejujuran, kepedulian, kemandirian, kedisiplinan, pertanggungjawaban, kerja keras, kesederhanaan, keberanian, dan keadilan. Nilai-nilai inilah yang akan mendukung prinsip-prinsip anti korupsi untuk dapat dijalankan dengan baik, yakni prinsip antikorupsi akuntabilitas, transparansi, kewajaran, kebijakan, dan kontrol kebijakan dalam suatu organisasi/institusi/masyarakat.

Kedua, Pencegahan korupsi hanya dimulai dengan munculnya rasa ketakutan untuk melakukan pelanggaran pada peraturan pelaksanaan penggunaan dana desa tersebut, jadi tidak ada kegiatan yang berbeda antara kegiatan desa dengan instruksi dari Dinas PMD, sementara yang ketiga adalah pembahasan mengenai pencegahan korupsi seakan merupakan pembahasan yang dihindari oleh para informan, sehingga tidak banyak informasi baru dan mendasar yang menunjukkan bahwa ada upaya pencegahan dalam perencanaan, pelaksanaan dan evaluasi kegiatan-kegiatan dana desa.

\section{Kesimpulan}




\begin{tabular}{llrr} 
Volume: & 3 & E-ISSN: & $2655-1942$ \\
Number: & 1 & Terbitan: & April 2020 \\
Page : & $29-41$ & & \\
\hline
\end{tabular}

Hambatan atas perwujudan pencegahan korupsi pada penggunaan dana desa pada Dinas Pemerintahan Masyarakat dan Desa, pemerintah desa dan tim pelaksana kegiatan adalah pertama, pemahaman yang rendah mengenai gerakan anti korupsi berupa pemenuhan unsur monitoring dan evaluasi, pemenuhan dokumen saat perencanaan dan pelaksanaan dan administrasi kegiatan. Kedua, bentuk pencegahan korupsi adalah dengan adanya rasa ketakutan untuk melakukan pelanggaran pada peraturan pelaksanaan penggunaan dana desa tersebut. Ketiga, pembahasan mengenai Pencegahan korupsi seakan merupakan kajian yang baru dan bersifat tabu untuk diadakan pembahasan lebih lanjut. Rekomendasi atas penelitian ini adalah bahwa pihak-pihak yang bertanggung jawab atas penggunaan dalam desa memerlukan informasi spesifik mengenai upaya pencegahan korupsi, sekaligus sebagai wujud pertanggungjawabkan kepada masyarakat.

\section{Daftar Pustaka}

\section{Buku:}

Prasojo, E. 2005. Demokrasi di Negeri Mimpi: Catatan Kritis Pemilu 2004 dan Good Governance. Depok.

Sugiyono. 2010. Metode Penelitian Pendidikan Pendekatan Kuantitatif, kualitatif, dan R\&D. Bandung: Alfabeta.)

Suharsimi Arikunto, 2013. Prosedur Penelitian Suatu Pendekatan Praktik. Jakarta. Rineka Cipta.

\section{Internet:}

Aryadji. Awas, sekarang polisi ikut awasi dana desa. diakses tanggal 23 Oktober 2017. http://www.berdesa.com/awas-sekarang-polisi-ikut-awasi-dana-desa/

Direktorat jenderal Perimbangan Keuangan Kementerian Keuangan. diakses 17 April 2019.

Http://www.djpk.kemenkeu.go.id/?ufaq=bagaimana-penggunaan-dana-desa

Kementerian Ppn/Bappenas Ri, 2014. Hasil Kajian Background Study Rpjmn 2015-2019

Pembangunan Bidang Aparatur Negara.. Direktorat Aparatur Negara Kementerian 
Law, Development \& Justice Review

\begin{tabular}{llrr}
\hline \hline Volume: & 3 & E-ISSN: & $2655-1942$ \\
Number: & 1 & Terbitan: & April 2020 \\
Page : & $29-41$ & & \\
\hline
\end{tabular}

Perencanaan Pembangunan Nasional/ Badan Perencanaan Pembangunan Nasional Tahun 2014.

Risman. Polres Gowa usut penyalahgunaan 32 kasus dana desa, ditulis pada 6 maret 2019. Https://suarapalu.com/polres-gowa-usut-penyalahgunaan-32-kasus-dana-desa/.

\section{Peraturan Perundang-Undangan:}

Peraturan Menteri Desa Pembangunan Daerah Tertinggal dan Transmigrasi Nomor 19 Tahun 2017 tentang Penetapan Prioritas Dana Desa tahun 2018

Peraturan Bupati Gresik Nomor 55 Tahun 2016 Tentang Kedudukan, Susunan Organisasi 